\title{
Factors Influencing the Use of ICT for English Language Learning of Indonesian EFL University Students
}

\author{
Tubagus Zam Zam Al Arif *, \& Reli Handayani \\ Universitas Jambi, Jambi, Indonesia \\ *zamzam@unja.ac.id
}

\section{ARTICLE HISTORY \\ Received : 27 May 2021 \\ Revised : 4 October 2021 \\ Accepted : 9 November 2021}

\section{KEYWORDS}

Information and Communication Technology (ICT)

Indonesia

Structural Equation Modelling Technology Acceptance Model (TAM) University Students

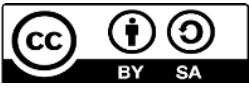

\begin{abstract}
This study examines the factors of the Technology Acceptance Model (TAM) that influence the acceptance of ICT use for English language learning of EFL University Students. This study also addresses the possible obstacles that affect and limit the use of ICT by adding motivation and ICT skills as extended TAM variables. This area of research topic is unexplored in the Indonesian context, especially in higher education institution. An analysis of these factors can assist instructors to understand how students learn using ICT and in providing useful advice to them during the learning process. The quantitative method was applied in this study, which included 303 students' teachers of English Education at a state university in Jambi, Indonesia. The instrument used in collecting the data was an online questionnaire. Data collected were analyzed by using Structural Equation Modeling (SEM) with SmartPLS3 program to analyze the proposed hypotheses formed in order to meet the study objectives. The SEM result indicated that the factors of the technology acceptance model are the main factors affecting the ICT use. The study concluded that the influence of motivation and skills for ICT usage was mediated by three main TAM variables, namely perceived ease of use, perceived usefulness, and attitudes.
\end{abstract}

\section{Introduction}

The technological advances have had a major effect on the field of education, especially in the study of English as a foreign language. The ICT use in learning English can help students improve their language skills, and also, ICT use can inspire and encourage students in English language learning. ICT usage can offer opportunities for collaboration and participation in the English learning process, however, those opportunities must be scaffolded for learners to take benefit from those opportunities (Murray, 2005).

Literacy in ICT is not a new notion. Indeed, computer literacy claims may be traced back to the 1980s. However, the phrase "computer literacy" is frequently inadequately defined and delimited, both in terms of its general goals and what it really involves. Computer literacy rationales are frequently founded on questionable assumptions on the occupational relevance of technology skills or the intrinsic benefit of learning with technology, which have been broadly disputed.

In everyday use, computer literacy appears to be a minimal set of abilities that will allow the user to function efficiently with technology devices or execute basic information retrieval activities. This is basically a functional definition, it describes the fundamental abilities necessary to carry out specific activities, but it does not go very far beyond that.
The majority of discussions about digital literacy remain focused on information and communication technologies (ICT). As a result, they tend to overlook some of the larger cultural uses of the internet (particularly among teenagers), which are not just about information retrieval, but also about entertainment, play, personal conversation - and even online commerce. To a great part, the goal here is to encourage more efficient uses of ICT - for instance, by developing sophisticated search abilities that will make it simpler to discover relevant resources on the internet.

In recent decades, information and communication technology (ICT) has been more widely used in language teaching and learning. ICT refers to computer-based and internet-based technologies that are used to create, store, view, and share information. ICT offers a system for knowledge processing, display, distribution, and exchange, as well as a context for human-human and human-machine communication. In the sense of EFL, ICT may provide opportunities for English language learners to communicate with native speakers through ICT resources such as e-mail, social networking, and video-based communication such as Skype, Zoom, and Google Meet.

Both teachers and students will benefit from the use of ICT in English language learning. ICT has been used in schools ranging from primary to higher education. Students may use ICT to find out about new learning materials and practice their English language skills. Furthermore, ICT can 
be used to draw and increase students' attention and optimistic attitudes toward English learning, and it is proposed that ICT can be used more often in the classroom to maximize language teaching and learning. The use of ICT will provide students with opportunities to learn their English in real-world contexts (Kramsch \& Thorne, 2002). The students may use Zoom or Skype to interact with a native speaker (Dalton, 2011). In addition, teachers should use video resources in the classroom to improve English language learning (Boutonglang \& Flores, 2011). ICT can be used to help students enhance their English language skills (listening, speaking, reading, writing) (Jakob \& Afdaliah, 2019).

In the English language teaching method, the use of ICT will assist English language learners in improving their English language skills. When teachers use ICT in the English language teaching process, university students are more involved in studying the language. Students become more involved and embrace classroom experiences as a result of the impact of technology use in the classroom. The introduction of ICT also enhances students' enthusiasm in the sense of EFL (Ilter, 2009).

In the Indonesian context, especially in the English Study Program of a state university in Jambi, the students believe that ICT is useful to be implemented in English language learning. They used ICT only for the presentation media in teaching and learning process in the classroom (Oktalia et al., 2018). Furthermore, the students used ICT to enrich their knowledge related to the topic given by the lecturer. Meanwhile, the lecturer used the ICT for displaying content and as a media for presentation in the teaching and learning process. Therefore, ICT integration needs to be explored further in order to identify the factors of the technology acceptance model affecting the ICT use for English language learning inside and outside the classroom.

The focus of this study is to explore the students' acceptance towards the use of ICT in English language learning by using Technology Acceptance Model (TAM) in order to know the effects of each construct in this model. The analysis of findings is extended by using structural equation modeling (SEM) to explore the determinants of ICT use for learning English by EFL university students.

Different from the previous studies (Alfarwan, 2019; Scherer et al., 2019; Tri \& Nguyen, 2014; Wang \& Hsu, 2020), this current study investigated the attitudes of students towards technology use in learning English by employing TAM which is more comprehensive. Sabti \& Chaichan (2014) also employs TAM model, yet they limited the variables involved. Thus, the novelty of this study is the extension of the basic TAM with adding motivation and ICT skills as variables of TAM to explore the determinants of ICT use in learning English. Moreover, this area of research covers Indonesian context, especially in higher education institution which haven't been explored. Thus, this study issue has yet to be addressed in Indonesian setting. Analysis of these variables might help, specifically Indonesian teachers to understand how students learn English using ICT and provide them with valuable suggestions during the learning process.

This study can inform both teachers and students on the importance of incorporating technology in English language learning and teaching. As a result, the aim of this study is to examine the determinants of TAM that affect the acceptance of ICT usage for English language learning. This study attempts to analyze the relationship of students' attitudes towards the use of ICT with determined constructs namely motivation and ICT skills to use ICT for English language learning.

\section{Literature Review}

\subsection{Information and Communication Technology}

Information and communication technology (ICT) refers to technologies that are used to create, display, store, manipulate, and share information (Meleisea, 2007). ICT refers to computer-based technologies and network-based technologies that provide a context for information production, delivery, and sharing (Murray, 2005). Generally, ICT relates to computers, laptops, smartphones, gadgets, networks, the internet and other computer-based technologies. ICT has brought great changes to all fields of our lives, and it plays an important part in education. In the last decade, ICT use has made a significant contribution to English language learning.

ICT covers all parts of computers, internet, networks, and specific other devices with information storage and processing capacities such as TV, mobile phones, and automatic control devices (Kennewell, 2004). In this current study, ICT refers to computer-based technologies and internet based-technologies such as computers, laptops, smartphones, social networking, website, and software related to English language learning and teaching (Davies \& Hewer, 2009).

The ICT integration in English language learning will attract the students' interest and motivation. The students are more interested when English language learning is taught by using technology in the classroom. The technology integration will affect the students' attitudes and motivation. The students will enjoy the English language learning activities and they will become active learners in English language learning process.

\subsection{ICT in English Language Learning and Teaching}

With the first appearance of ICT use in education in the last few decades, considerable investment in technology facilities and training has been made in Indonesian universities. As in other nations, the use of ICT in education 
in Indonesia focuses on the possible contribution of computer technologies in teaching and learning process. ICT enables students to actively participating in training and learning experiences. As ICT is used in English language teaching and learning, students have a good understanding and outlook towards technology integration in the classroom (Boutonglang \& Flores, 2011).

The ICT integration in the classrooms has a great potential for English language learning. It can provide active learning experiences and motivate the students. Technological devices such as computer, TV, Laptop, Projector, and interactive learning video will affect the students' attitudes in English language learning and teaching process. The students can improve their English language skills and provide a sense of mobility and encouragement using kinds of technological devices (Krista \& Jay, 2001).

In this digital era, both teachers and students are demanded to have digital literacy. It means that mastering the ICT skills is a must for teachers and students. They should have the resources and knowledge necessary to use ICT in English language learning. The ICT skills will drive both teachers and students to gain the benefit of ICT use for English language learning.

\subsection{The Benefits of ICT for English Language Learning and Teaching}

Many results of studies are made about the benefits of ICT integration in English Language Learning and Teaching. Technological devices, including the internet and applications, makes the process of teaching and learning more comfortable and easier, but it also increases the students' motivation and engagement (Fatiha et al., 2014; Ilter, 2009). The ICT integration brings many benefits to students. The students may have the opportunity to search for a variety of authentic materials. The benefits of using ICT in ELT, such as developing Social Networking Services (SNS), social interaction (discussion and forum for students to interact with supervisors or instructors), learning motivation, and experience supports (Habibi et al., 2018).

The implementation of ICT in ELT will help both teachers and students. Technology devices have been recognized as important and useful resources, especially in the teaching of English. The use of ICT in ELT assists students in improving their attitudes toward learning English (Idowu \& Gbadebo, 2017; Sabti \& Chaichan, 2014). The implementation of ICT in the classroom may result in positive attitudes among both teachers and learners (Benghalem, 2015; Rahim \& Chandran, 2021).

Furthermore, other studies were undertaken to affirm the effects of ICT integration in English language learning and teaching often rely on bringing learners to new computers, apps, and websites for learning and practicing English. (Zhang et al., 2011). Learners may use a wide variety of computers, apps, and websites to help them develop their
English skills. Internet-based technologies provide learners with access to authentic materials, allowing them to experience English language learning in the real context (Shevchenko, 2018). These devices enable students to interact, collaborate, and experience learning in authentic environments.

Sabti \& Chaichan (2014) reported their study which focuses on investigating the students' attitudes and barriers. This study involved 30 Saudi Arabia students from a high school in Kuala Lumpur, Malaysia. The result of this study revealed gender differences affects the students' attitudes towards the use of technologies in learning English. Female students showed high and positive attitudes than males.

Alfarwan (2019) investigated ICT roles in learning and using English among EFL university students. This study surveyed 138 Saudi English and business students at a Saudi university. The findings indicated that the smartphone has the most significant potential for further exploitation concerning English, followed by the laptop and tablet.

Tri \& Nguyen (2014) explored the perceptions among teachers and students of ICT usage. It undertook 149 EFL students at a university in Vietnam who responded to the questionnaire survey. The findings indicated that the learners spent more time using ICT for private purposes than for English learning purposes. Specifically, 88,4\% of them using ICT for general purposes, and $12.6 \%$ of them used ICT for English learning purposes.

\subsection{Technology Acceptance Model}

The technology acceptance model (TAM) is a valid model which includes the perceived usefulness (PU) and perceived ease of use (PEoU) as beliefs on a new technology that affect attitude on the use of that technology (Davis et al., 1989). The TAM has been applied in the context of language learner's behavior (Alfarwan, 2019; Sabti \& Chaichan, 2014; Scherer et al., 2019; Wang \& Hsu, 2020). Furthermore, multiple studies have provided empirical evidence for the TAM concept (Venkatesh and Davis, 2000).

Despite widespread acceptance for the TAM, researchers urge others to investigate whether the TAM's belief variables are mediators of the effect of external variables and, if so, which external variables are essential (Venkatesh, 2000; Venkatesh and Brown, 2001). There is no previous literature research has included collectively motivation and ICT skills in a single TAM model, even though these variables are relevant in the context of exploring ICT use for English language learning. Also, while previous research shows that access barriers, such as cost, could influence the use of personal technology (Venkatesh and Davies, 2000), perceived of motivation and ICT skills have not been included as an additional belief variable in previous applications of the TAM. 
Therefore, we addressed this gap on the research body by extending the TAM with adding perceived motivation and ICT skills constructs among the key beliefs on ICT use for English language learning as external variables of TAM. Our model suggests that the TAM's external variables are relevant to learners with different demographic profiles and serve to mediate the relationships between attitude and actual usage of ICT for English language learning.

\section{Method}

The current study employed a quantitative method to explore the impact of ICT use for English language learning purposes. Furthermore, it investigates the students' practices towards the use of ICT for general purposes and English language learning purposes. The questionnaire was distributed randomly to 303 students of the English Department of Jambi University. The respondents had learned English formally for approximately three years in secondary school, and three years in high school, also additional English Education classes at university. Two hundred thirty-seven respondents are female, while sixty-six respondents are male.
The two-section of the questionnaire was designed in a close-ended format. Background information was gathered in the first section. The second section covered the TAM variables in using ICT for English language learning which are motivation (Mo), skills (Sk), perceived ease of use (PEoU), perceived usefulness (PU), attitude (At), and actual use $(A U)$ with four rating scales ranging from agree to disagree. Before the instrument administrated for data collection, it was piloted on a diverse sample of respondents who were not included in the main study, allowing the researchers to classify and modify the instrument to ensure its validity and reliability. The instrument also was translated into the Indonesian language to ensure the respondents' comprehension of the items.

The data were analyzed quantitatively by using structural equation modeling with SmartPLS3 program was used to analyze the participants responses. Confirmatory factor analysis was performed to examine the impact of TAM factors that influence the ICT usage for English learning purposes.

Based on the study objectives and previous literature studies, this study tested the following hypotheses:

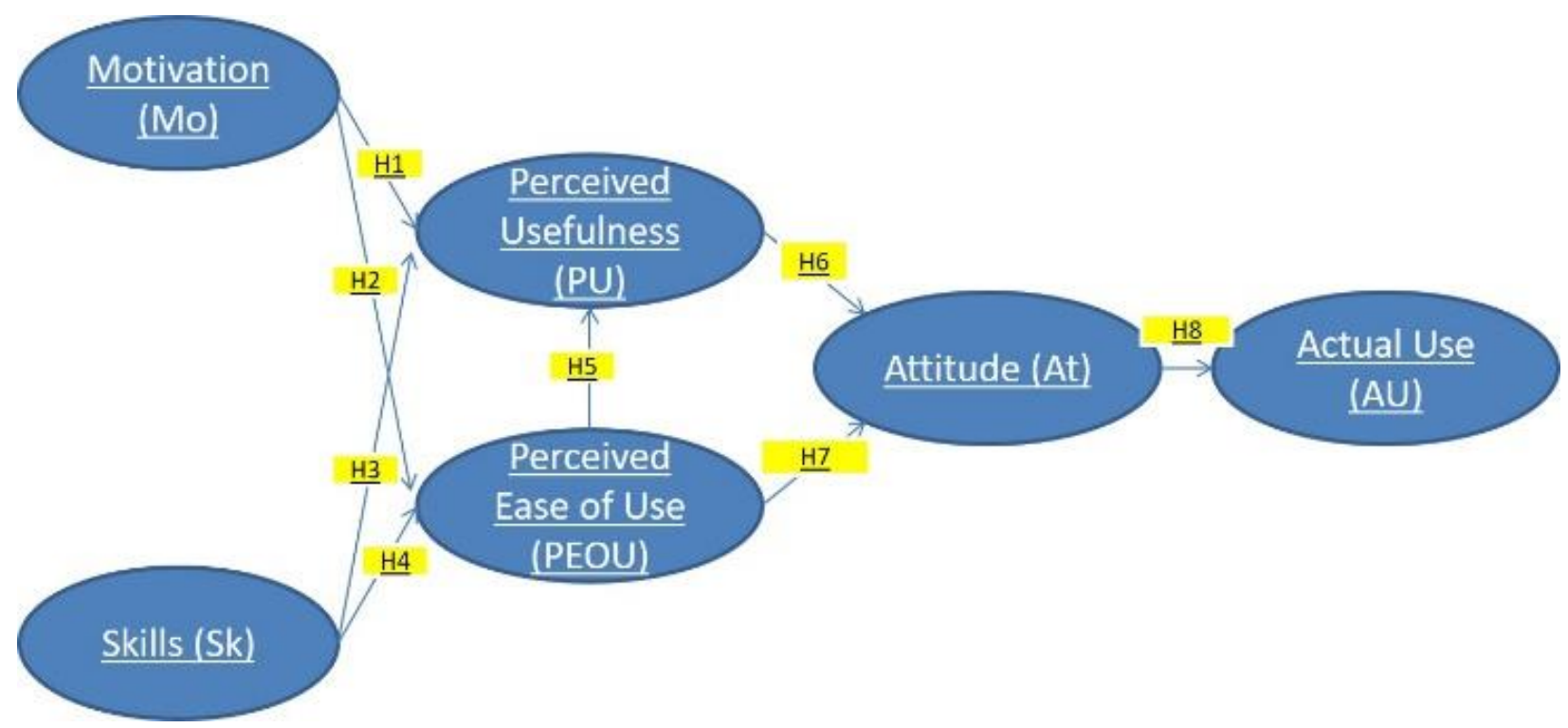

Figure 1. Proposed Research Hypothesis

The researchers used the extended Technology Acceptance Model (TAM) to investigate factors influencing the ICT use in English language learning. TAM is a valid model which was developed to understand technology acceptance and usage process (Davies, 1989; Venkatesh et al, 2003). The original TAM model included Perceived Ease of Use (PEoU), Perceived Usefulness (PU), Attitude (At), and Actual use (AU). In TAM model, the behavioral intention to use technology is determined by PEoU, PU and
At, while PEoU and PU mediate the effect of external variables (e.g., social norms, affording or constraining factors in the environment)

In this current study, the researchers added motivation and ICT Skills as external variables of TAM. Motivation and ICT Skills were predicted to mediate PEoU and PU, and determined attitude and actual ICT use in English language learning. Hence, this study has six constructs to investigate 
factors influencing the use of ICT for English language learning by EFL university students.

From these six constructs (motivation, ICT skills, perceived ease of use, perceived usefulness, attitude, and actual use), eight hypotheses emerge to be tested in this study. The hypotheses are presented in Table 1.

Table 1. Hypotheses

\begin{tabular}{|c|c|c|}
\hline No. & & Hypotheses \\
\hline \multirow[t]{2}{*}{ H1 } & $\mathrm{H}_{0}$ & $\begin{array}{l}\text { There is no a significant effect of Motivation } \\
\text { on Perceived Usefulness }\end{array}$ \\
\hline & $\mathrm{Ha}$ & $\begin{array}{l}\text { There is a significant effect of Motivation on } \\
\text { Perceived Usefulness }\end{array}$ \\
\hline \multirow[t]{2}{*}{$\mathrm{H} 2$} & $\mathrm{H}_{0}$ & $\begin{array}{l}\text { There is no a significant effect of Motivation } \\
\text { and Perceived Ease of Use }\end{array}$ \\
\hline & $\mathrm{H}_{\mathrm{a}}$ & $\begin{array}{l}\text { There is a significant effect of Motivation and } \\
\text { Perceived Ease of Use }\end{array}$ \\
\hline \multirow[t]{2}{*}{ H3 } & $\mathrm{H}_{0}$ & $\begin{array}{l}\text { There is no a significant effect of ICT Skills on } \\
\text { Perceived Usefulness }\end{array}$ \\
\hline & $\mathrm{H}_{\mathrm{a}}$ & $\begin{array}{l}\text { There is a significant effect of ICT Skills on } \\
\text { Perceived Usefulness }\end{array}$ \\
\hline $\mathrm{H} 4$ & $\mathrm{H}_{0}$ & $\begin{array}{l}\text { There is no a significant effect of ICT Skills on } \\
\text { Perceived Ease of Use }\end{array}$ \\
\hline
\end{tabular}

\begin{tabular}{|c|c|c|}
\hline & $\mathrm{H}_{\mathrm{a}}$ & $\begin{array}{l}\text { There is a significant effect of ICT Skills on } \\
\text { Perceived Ease of Use }\end{array}$ \\
\hline \multirow[t]{2}{*}{ H5 } & $\mathrm{H}_{0}$ & $\begin{array}{l}\text { There is no a significant effect of Perceived } \\
\text { Ease of Use on Perceived Usefulness }\end{array}$ \\
\hline & $\mathrm{H}_{\mathrm{a}}$ & $\begin{array}{l}\text { There is a significant effect of Perceived Ease } \\
\text { of Use on Perceived Usefulness }\end{array}$ \\
\hline \multirow[t]{2}{*}{ H6 } & $\mathrm{H}_{0}$ & $\begin{array}{l}\text { There is no a significant effect of Perceived } \\
\text { Usefulness on Attitude }\end{array}$ \\
\hline & $\mathrm{H}_{\mathrm{a}}$ & $\begin{array}{l}\text { There is a significant effect of Perceived } \\
\text { Usefulness on Attitude }\end{array}$ \\
\hline \multirow[t]{2}{*}{ H7 } & $\mathrm{H}_{0}$ & $\begin{array}{l}\text { There is no a significant effect of Perceived } \\
\text { Ease of Use on Attitude }\end{array}$ \\
\hline & $\mathrm{H}_{\mathrm{a}}$ & $\begin{array}{l}\text { There is a significant effect of Perceived Ease } \\
\text { of Use on Attitude }\end{array}$ \\
\hline \multirow[t]{2}{*}{ H8 } & $\mathrm{H}_{0}$ & $\begin{array}{l}\text { There is no a significant effect of Attitude on } \\
\text { Actual Use }\end{array}$ \\
\hline & $\mathrm{H}_{\mathrm{a}}$ & $\begin{array}{l}\text { There is a significant effect of Attitude on } \\
\text { Actual Use }\end{array}$ \\
\hline
\end{tabular}

\section{Results}

This section describes the findings, statistical descriptive, significance, validity, reliability, and hypothesis testing.

Table 2. Statistic Descriptive

\begin{tabular}{|c|c|c|c|c|c|c|c|c|}
\hline Constructs & Items & Mean & Median & Min & Max & Standard Deviation & Excess Kurtosis & Skewness \\
\hline \multirow[t]{2}{*}{ Motivation } & Mot1 & 3.558 & 4 & 2 & 4 & 0.503 & -1.714 & -0.312 \\
\hline & Mot2 & 3.426 & 3 & 2 & 4 & 0.514 & -1.48 & 0.081 \\
\hline \multirow[t]{2}{*}{ ICT Skills } & Skill1 & 3.683 & 4 & 2 & 4 & 0.472 & -0.966 & -0.886 \\
\hline & Skill2 & 3.502 & 4 & 2 & 4 & 0.532 & -1.185 & -0.337 \\
\hline \multirow[t]{5}{*}{ Perceived Ease of Use } & PEOU1 & 3.347 & 3 & 1 & 4 & 0.553 & -0.027 & -0.194 \\
\hline & PEOU2 & 3.323 & 3 & 1 & 4 & 0.527 & 0.084 & -0.001 \\
\hline & PEOU3 & 3.168 & 3 & 1 & 4 & 0.552 & 0.546 & -0.061 \\
\hline & PEOU4 & 3.475 & 3 & 1 & 4 & 0.544 & -0.134 & -0.459 \\
\hline & PEOU5 & 3.330 & 3 & 1 & 4 & 0.577 & -0.049 & -0.291 \\
\hline \multirow[t]{8}{*}{ Perceived Usefulness } & PU1 & 3.172 & 3 & 2 & 4 & 0.583 & -0.267 & -0.043 \\
\hline & PU2 & 3.419 & 3 & 2 & 4 & 0.568 & -0.8 & -0.33 \\
\hline & PU3 & 3.287 & 3 & 2 & 4 & 0.563 & -0.532 & -0.054 \\
\hline & PU4 & 3.089 & 3 & 1 & 4 & 0.681 & 0.035 & -0.365 \\
\hline & PU5 & 3.119 & 3 & 1 & 4 & 0.664 & 0.274 & -0.409 \\
\hline & PU6 & 3.172 & 3 & 1 & 4 & 0.572 & 0.319 & -0.116 \\
\hline & PU7 & 3.251 & 3 & 2 & 4 & 0.588 & -0.485 & -0.126 \\
\hline & PU8 & 3.554 & 4 & 3 & 4 & 0.497 & -1.965 & -0.22 \\
\hline \multirow[t]{4}{*}{ Attitude } & Att1 & 3.574 & 4 & 2 & 4 & 0.520 & -1.038 & -0.583 \\
\hline & Att2 & 3.568 & 4 & 2 & 4 & 0.528 & -0.911 & -0.612 \\
\hline & Att3 & 3.426 & 3 & 1 & 4 & 0.563 & -0.097 & -0.429 \\
\hline & Att4 & 3.630 & 4 & 2 & 4 & 0.509 & -0.62 & -0.842 \\
\hline Actual Use & AU1 & 3.370 & 3 & 2 & 4 & 0.576 & -0.721 & -0.258 \\
\hline
\end{tabular}




\begin{tabular}{llllllll} 
AU2 & 2.723 & 3 & 1 & 4 & 0.696 & -0.273 & -0.035 \\
AU3 & 3.056 & 3 & 1 & 4 & 0.699 & -0.012 & -0.369 \\
\hline
\end{tabular}

Table 2 above showed the statistic descriptive of six variables of this study. All items mean scores ranged from 2.723 to 3.683 which means slightly agree to above moderately agree. However, the standard deviations (SD) were relatively moderate $(0.472$ to 0.699$)$, indicated that there were considerable variations among respondents.

Table 3. Convergent Validity

\begin{tabular}{lccc}
\hline \multicolumn{1}{c}{ Construct } & Items & $\begin{array}{c}\text { Average } \\
\text { Outer } \\
\text { Loading }\end{array}$ & $\begin{array}{c}\text { Variance } \\
\text { Extracted } \\
\text { (AVE) }\end{array}$ \\
\hline Motivation & Mot1 & 0.867 & 0.786 \\
ICT Skills & Mot2 & 0.906 & \\
Perceived Ease of Use & Skill1 & 0.835 & 0.772 \\
& Skill2 & 0.921 & \\
& PEOU1 & 0.833 & 0.649 \\
& PEOU2 & 0.877 & \\
& PEOU3 & 0.764 & \\
& PEOU4 & 0.736 & \\
& PEOU5 & 0.809 & \\
& &
\end{tabular}

$\begin{array}{llll}\text { Perceived Usefulness } & \text { PU1 } & 0.785 & 0.511 \\ & \text { PU2 } & 0.682 & \\ & \text { PU3 } & 0.661 & \\ & \text { PU4 } & 0.680 & \\ & \text { PU5 } & 0.678 & \\ & \text { PU6 } & 0.764 & \\ \text { Attitude } & \text { PU7 } & 0.800 & \\ & \text { PU8 } & 0.653 & \\ & \text { Att1 } & 0.814 & 0.653 \\ \text { Actual Use } & \text { Att2 } & 0.836 & \\ & \text { Att3 } & 0.840 & \\ & \text { Att4 } & 0.737 & \\ & \text { AU1 } & 0.851 & 0.685 \\ & \text { AU2 } & 0.797 & \\ & \text { AU3 } & 0.834 & \end{array}$

Table 3 above shows the convergent validity. The score of outer loading of each item $>0.70$ and the count of average variance extracted $(\mathrm{AVE})>0.50$, it means that the entire items are valid.

Table 4. Discriminant Validity with Fornell-Larcker Criterion

\begin{tabular}{lccccccc}
\hline Constructs & $\begin{array}{c}\text { Actual } \\
\text { Use }\end{array}$ & Attitude & Equipment & $\begin{array}{c}\text { ICT } \\
\text { Skills }\end{array}$ & Motivation & Perceived Ease of Use & $\begin{array}{c}\text { Perceived } \\
\text { Usefulness }\end{array}$ \\
\hline Actual Use & $\mathbf{0 . 8 2 8}$ & & & & & & \\
Attitude & 0.536 & $\mathbf{0 . 8 0 8}$ & & & & & \\
ICT Skills & 0.312 & 0.408 & 0.407 & $\mathbf{0 . 8 7 9}$ & & & \\
Motivation & 0.417 & 0.487 & 0.388 & 0.324 & $\mathbf{0 . 8 8 7}$ & & \\
Perceived Ease of Use & 0.460 & 0.461 & 0.443 & 0.499 & 0.318 & $\mathbf{0 . 8 0 5}$ & $\mathbf{0 . 7 1 5}$ \\
Perceived Usefulness & 0.567 & 0.643 & 0.339 & 0.362 & 0.498 & & 0.553 \\
\hline
\end{tabular}

Table 4 above shows the discriminant validity. It was done to test the discriminant validity by using the fornelllarcker criterion. The score of actual use is 0.828 , attitude
0.808 , ICT Skills 0.879, motivation 0.887, PEOU 0.805, and PU 0.715. each construct has a score $>0,7$. It means that each construct is valid.

Table 5. Reliability

\begin{tabular}{lcccc}
\hline Constructs & Cronbach's Alpha & rho_A & Composite Reliability & Average Variance Extracted (AVE) \\
\hline Actual Use & 0.773 & 0.791 & 0.867 & 0.685 \\
Attitude & 0.822 & 0.828 & 0.882 & 0.653 \\
ICT Skills & 0.713 & 0.771 & 0.871 & 0.772 \\
Motivation & 0.730 & 0.743 & 0.880 & 0.786
\end{tabular}




\begin{tabular}{lllll} 
Perceived Ease of Use & 0.863 & 0.865 & 0.902 & 0.649 \\
Perceived Usefulness & 0.862 & 0.867 & 0.893 & 0.511 \\
\hline
\end{tabular}

Table 5 above shows the reliability of the instrument. In testing the reliability of the instrument, we used Cronbach's alpha, rho_A, composite reliability, and AVE. the results of data analysis indicate that the scores Cronbach's alpha are $>$ 0.70 , rho_A $>0.70$, composite reliability $>0.70$, and AVE > 0.50 . It means that the entire constructs are reliable.

Table 6. Hypothesis Testing

\begin{tabular}{|c|c|c|c|c|c|c|}
\hline Hypothesis & Path & $\begin{array}{c}\text { Original } \\
\text { Sample } \\
(\mathbf{O})\end{array}$ & $\begin{array}{c}\text { Sample } \\
\text { Mean } \\
\text { (M) }\end{array}$ & $\begin{array}{l}\text { Standard } \\
\text { Deviation } \\
\text { (STDEV) }\end{array}$ & $\begin{array}{c}\text { T Statistics } \\
(\mid \text { O/STDEV } \mid)\end{array}$ & $\begin{array}{c}\mathbf{P} \\
\text { Values }\end{array}$ \\
\hline $\mathrm{H} 1$ & Motivation -> Perceived Usefulness & 0.352 & 0.354 & 0.049 & 7.143 & 0.000 \\
\hline $\mathrm{H} 2$ & Motivation -> Perceived Ease of Use & 0.102 & 0.101 & 0.061 & 1.654 & 0.049 \\
\hline $\mathrm{H} 3$ & ICT Skills -> Perceived Usefulness & 0.037 & 0.037 & 0.056 & 0.663 & 0.254 \\
\hline $\mathrm{H} 4$ & $\begin{array}{l}\text { ICT Skills }->\text { Perceived Ease of Use } \\
\text { Perceived Ease of Use -> Perceived }\end{array}$ & 0.361 & 0.359 & 0.066 & 5.493 & 0.000 \\
\hline H5 & Usefulness & 0.423 & 0.425 & 0.061 & 6.973 & 0.000 \\
\hline H6 & Perceived Usefulness -> Attitude & 0.560 & 0.560 & 0.056 & 9.963 & 0.000 \\
\hline H7 & Perceived Ease of Use -> Attitude & 0.151 & 0.151 & 0.069 & 2.197 & 0.014 \\
\hline $\mathrm{H} 8$ & Attitude $->$ Actual Use & 0.536 & 0.540 & 0.047 & 11.399 & 0.000 \\
\hline
\end{tabular}

The findings in this study showed that Hypothesis 1 (H1), the influence of Motivation (Mo) on Percived Usefulness (PU) with t-statistics $=7.143$ and $\mathrm{p}$-Value $=0.000$, it means that there was a significant positive influence of Mo on PU. H2 Motivation (Mo) on Perceived Ease of Use (PEoU) with $\mathrm{t}$-statistics $=1.654$ and $\mathrm{p}$-Value $=0.049$, it means that there was no significant influence of Mo on PEoU. H3 ICT Skills (Sk) on Perceived Usefulness with t-statistics $=0.663$ and $\mathrm{p}$ Value $=0.254$, it means that there was no significant influence of Sk on PU. H4 ICT Skills (Sk) - PEoU with tstatistics $=5.493$ and $\mathrm{p}$-Value $=0.000$, it means that there was a significant influence of Sk on PEoU. H5 Perceived Ease of Use (PEoU)on Perceived Usefulness (PU) with tstatistics $=6.973$ and $p$-Value $=0.000$, it means that there was a significant influence of PEoU on PU. H6 Perceived Usefulness (PU) on Attitude (At) with t-statistics = 9.963 and p-Value $=0.000$, it means that there was a significant influence of PU on At. H7 Perceived Ease of Use (PEoU) on Attitude (At) with t-statistics $=2.197$ and $\mathrm{p}$-Value $=0.014$, it means that there was a significant influence of PEoU on At. H8 Attitude (At) on Actual Use (AU) with t-statistics = 11.399 and $\mathrm{p}$-Value $=0.000$, it means that there was a significant influence of At on AU.

From the findings above, we can conclude that $\mathrm{H} 1, \mathrm{H} 4$, H5, H6, H7, H8, have t-statistics > 1.96 and P-Value $<0.05$. So that $\mathrm{Ho}$ is rejected and $\mathrm{Ha}$ is accepted. It means that there is a significant effect between variables. The variables have significant effect namely, motivation on Perceived
Usefulness, ICT Skills on PEoU, PEoU on PU, PU on At, PEoU on At, and the last is At on AU. On the other hand, H2 and $\mathrm{H} 3$ have $t$-statistics $<1.96$ and $\mathrm{P}-$ Value $>0.05$. So that $\mathrm{Ho}$ is accepted, and $\mathrm{Ha}$ is rejected, it means that there is no significant effect between variables. The variables have no significant effect namely, Mo on PEoU, and Sk on PU.

Results of the hypothesis analysis are shown in table 5, there are six construct that have significant effect related to actual use of ICT for learning English. Most of the research hypotheses were strongly supported except for $\mathrm{H} 2$ and $\mathrm{H} 3$. For H1, the result indicated that Motivation has a significant effect on Perceived Usefulness, it means that Motivation has an indirect effect on the Actual Use through Perceived Usefulness. Motivation on Perceived Ease of Use has no significant effect $(\mathrm{H} 2)$. It means that Motivation has no indirect effect on Actual Use through Perceived Ease of Use. Not only H2, but also H3 which not support the hypotheses. H3, where ICT Skills on Perceived Usefulness has no significant effect. It means ICT skills has no significant indirect effect to Actual Use through Perceived Usefulness.

For H4, where ICT Skills has significant influence on Perceived Ease of Use, it means that ICT Skills has indirect effect on Actual Use through Perceived Ease of Use. H5 showed that Perceived Ease of Use has significant effect on Perceived Usefulness. It means that Perceived Ease of Use has direct and indirect effect on Actual Use through Perceived Usefulness. H6 indicated that Perceived Usefulness on Attitude has a significant effect. It means that 
Perceived Usefulness direct and indirect effect on Actual Use through Attitude.

Hypothesis 7 (H7) showed that Perceived Ease of Use on Attitude has a significant influence. It means that Perceived Ease of Use has direct and indirect effect on Actual Use through Attitude. Hypothesis 8 (H8) showed that students' attitude towards ICT use has a significant effect on Actual Use of ICT in learning English. It means that students' actual use can be predicted from the students' attitude towards ICT use in English language learning, which are affected significantly by perceived Ease of Use and Perceived Usefulness.

\section{Discussion}

The findings depart from several points that we have mentioned in the literature review. First, we employed Technology Acceptance Model (TAM) to examine determinants of ICT use for English language learning. Second, we extended the original TAM by adding (a) motivation as a variable of using ICT that explains student's attitude toward technology and (b) student's ICT skills as a variable that explains attitude toward the use of ICT, due to their significance in the context of ICT use for English language learning. We found that these variables of our extended TAM are relevant to predict students' attitude and mediate the relationships between attitude and actual use of ICT.

So, why do motivation on perceived ease of use (PEoU), and also ICT skills on perceived Usefulness (PU) have no significant effect? We found that motivation and ICT skills are associated differentially with particular beliefs about the use of ICT, and these beliefs mediate students' attitude toward the use of ICT, while the effect of perceived ease of use and perceived usefulness on attitude was significant. Similar to other relevance studies (Scherer et al., 2019; Wang \& Hsu, 2020; Weng et al., 2018) this study confirmed TAM to be a helpful model to predict and explain students' acceptance of ICT use in learning English. Findings of current study indicated that the model well-represented the data collection based on the result of statistical descriptive, significance, validity, and reliability.

The discussion of integrating technology and education has progressed beyond the issue of basic access. The focus is increasingly on what students and young generation need to know about information and communication technology. The kind of competence and understanding they require to acquire if they intend to utilize ICT critically and effectively. The discussion at the moment is about how does attitude affect the use of ICT by the students in learning English.

The interesting phenomenon of this study is that perceived Ease of Use (PEoU), perceived usefulness (PU), and attitude (AT) play an important role in affecting actual use of ICT for English language learning. In Indonesia, students are encouraged to use ICT in learning English.
Students may desire to use ICT so they can have English learning experience in the real context.

With the rapid advancement of technology, the majority of students' leisure-time experiences are spent utilizing ICT for general purposes. ICT tools are much more than information retrieval devices; they communicate pictures and imaginations, allow for imaginative self-expression and play, and facilitate as a medium for fun and entertainment. The internet technology, social media, games, Youtube, smartphones, and other modern technologies offer new ways of mediating, representing, and talking with the real world.

Outside of classroom, students engage with these digital tools not only as digital technologies, but also as cultural forms. They do not perceive them as basic technical tools, but rather as a part of their favorite culture and their daily experience. If educators would like to integrate technology in the classroom, they cannot afford to ignore these experiences. On the other hand, educator must equip students with ways to comprehend them. Students' attitudes toward using ICT for English learning should be improved to make them enjoy and learn English successfully.

Nowadays, ICT use is inextricably linked to humans. ICT satisfies the need for information and may assist in accessing and distributing information. It will also enhance the quality of human life because it can be used in the field of education, health, environment, and the social sector. In the EFL context, ICT provides students access to opportunities and assists them in improving English language skills for handling their learning (Al-Rahmi et al., 2019; Lai, 2013; Reinders \& White, 2016). Consequently, the ICT should be integrated in English language classroom in order to attract students' motivation, so they can have positive attitude in using ICT for English language learning.

The ICT integration can improve students' English language skills (Oktalia et al., 2018; Zhang \& Pérez-Paredes, 2019). The students also believe that utilizing ICT in the learning process makes ELL more fun. The students are also enthusiastic about the use of ICT in English language study (Mei et al., 2018; Sabti \& Chaichan, 2014; Tri \& Nguyen, 2014). Therefore, both teachers and students should have resources and ICT skills to explore the benefits of ICT for English language learning.

\section{Conclusion}

To conclude, based on the study objectives we proposed, not only does the impact of student perceptions on the use of technology in learning English have a positive effect, but also, the motivation towards the perceived usefulness (PU), and ICT Skills (Sk) towards Perceived Ease of Use (PEOU) aspect. While, there is an interesting phenomenon that there is no significant effect of the motivation factor towards students' perceived Ease of Use (PEOU), and Students ICT Skills towards perceived usefulness (PU) of ICT for learning English. 
We are all aware that ICT integration has a major impact on English language learning, especially among EFL school and university students. In today's digital age, the availability of ICT is needed to help students whose first language is not English, so they can develop their English language skills. Students in Indonesia, where English is learned as a foreign language, have recognized the relevance of using ICT in English learning. Students use ICT tools to learn English and have a positive attitude toward using ICT to learn English (Al Arif, 2019; Kessler, 2018).

As a result, the findings of this research are useful to students and teachers in both schools and universities. Students must prepare themselves with, ICT skills, motivation, and have positive attitudes towards the use of ICT in learning English. Teachers should help students and inspire them to have good attitudes and inspiration when learning English using ICT. Teachers should also develop their ICT skills so that they can have learning opportunities that meet the demands of students in today's modern world. Besides, this study enables other researchers to discover useful implications for undertaking experimental studies regarding ICT integration for English language learning and teaching in the future.

\section{Acknowledgement}

The authors would like to thank the sponsors of this study, the Research and Community Service Institution (LPPM) of Universitas Jambi, Indonesia.

\section{References}

Al-Rahmi, W. M., Yahaya, N., Aldraiweesh, A. A., Alamri, M. M., Aljarboa, N. A., Alturki, U., \& Aljeraiwi, A. A. (2019). Integrating Technology Acceptance Model with Innovation Diffusion Theory: An Empirical Investigation on Students' Intention to Use E-Learning Systems. IEEE Access, 7(c), 26797-26809. https://doi.org/10.1109/ACCESS.2019.2899368

Al Arif, T. Z. Z. (2019). Indonesian University Students' Perception and Expectation towards ICT Use in Learning English as a Foreign Language. Indonesian Journal of English Language Teaching and Applied Linguistics, 4(1), 133-145.

Alfarwan, S. (2019). University student access to and use of electronic devices: A latent English language learning potential. Teaching English with Technology, 19(1), 102-117.

http://cejsh.icm.edu.pl/cejsh/element/bwmeta1.eleme nt.desklight-464a8909-4333-48ea-a1d8cbb571df950e

Benghalem, B. (2015). The effects of using microsoft power point on EFL learners' attitude and anxiety. Advances in Language and Literary Studies, 6(6), 1-6. https://doi.org/10.7575/aiac.alls.v.6n.6p.1
Boutonglang, D., \& Flores, F. (2011). A study on integrating technology to engage 7 th graders into an English as a foreign language (EFL) classroom in a rural secondary school, Thailand. International Journal of Arts \& Sciences, 4(18), 195-206.

Dalton, M. L. (2011). Social Networking and Second Language Acquisition: Exploiting SkypeTM Chat for the Purpose of Investigating Interaction in L2 English Learning [Iowa State University, The USA]. http://lib.dr.iastate.edu/etd/10221/

Davies, G., \& Hewer, S. (2009). Introduction to New Technologies and How They Can Contribute to Language Learning and Teaching. Module 1.1. in G Davies (Ed.), Information and Communication Technology for Language Teachers (ICT4LT). Thames Valley University.

Fatiha, M., Sliman, B., Mustapha, B., \& Yahia, M. (2014). Attitudes and motivations in learning English as a foreign language. International Journal of Arts \& Sciences, 07(03), 117-128.

Habibi, A., Mukminin, A., Riyanto, Y., Prasojo, L. D., Sulistiyo, U., Sofwan, M., \& Saudagar, F. (2018). Building an online community: Student teachers' perceptions on the advantages of using social networking services in a teacher education program. Turkish Online Journal of Distance Education, 19(1), 46-61.

Idowu, S. O., \& Gbadebo, A. D. (2017). Extent of utilization of information and communication technology tools by English language teachers in Ijebu-Ode and Odogbolu local government areas of Ogun State, Nigeria. International Journal of Arts \& Sciences, 09(04), 589-596.

Ilter, B. G. (2009). Effect of technology on motivation in EFL classrooms. Turkish Online Journal of Distance Education, 10(4), 136-158.

Jakob, J. C., \& Afdaliah, N. (2019). Using oxford smart choice multi-ROM to develop the students' listening ability. Journal of Education, Literature, and Culture, 4(1), 25-34.

Kennewell, S. (2004). Meeting the Standards in Using ICT for Secondary Teaching. Routledge.

Kessler, G. (2018). Technology and the future of language teaching. Foreign Language Annals, 51(1). https://doi.org/10.1111/flan.12318

Kramsch, C., \& Thorne, S. L. (2002). Foreign Language Learning as Global Communicative Practice. In D. Block and D. Cameron (Eds), Globalization and Language Teaching. Routledge.

Krista, G., \& Jay, B. (2001). English in the digital age: 
Information and communications technology and the teaching of English. Journal of Adolescent \& Adult Literacy, 44(4), 388-390.

Lai, C. (2013). A framework for developing self-directed technology use for language learning. Language Learning and Technology, 17(2), 100-122.

Mei, B., Brown, G. T. L., \& Teo, T. (2018). Toward an Understanding of Preservice English as a Foreign Language Teachers' Acceptance of ComputerAssisted Language Learning 2.0 in the People's Republic of China. Journal of Educational Computing Research, 56(1), 74-104. https://doi.org/10.1177/0735633117700144

Meleisea, E. (2007). The UNESCO ICT in Education Program. United Nations, Education, Scientific, and Cultural Organization.

Murray, D. E. (2005). Technologies for second language literacy. Annual Review of Applied Linguistics, 25(1), 188-201.

Oktalia, D., Ngadiso, \& Supriyadi, S. (2018). Integrating ICT in English language learning: Students , perceptions of a state university in Jambi Province. International Journal of Language Teaching and Education, 2(1), 49-59.

Rahim, M. N., \& Chandran, S. S. C. (2021). Investigating EFL Students' Perceptions on E-learning ParadigmShift During Covid-19 Pandemic. Elsya : Journal of English Language Studies, 3(1), 56-66. https://doi.org/10.31849/elsya.v3i1.5949

Reinders, H., \& White, C. (2016). 20 years of autonomy and technology: How far have we come and where to next? Language Learning and Technology, 20(2), 143-154.

Sabti, A. A., \& Chaichan, R. S. (2014). Saudi high school students' attitudes and barriers toward the use of computer technologies in learning English. SpringerPlus, 3(1), 1-9. https://doi.org/10.1186/21931801-3-460

Scherer, R., Siddiq, F., \& Tondeur, J. (2019). The technology acceptance model (TAM): A meta-analytic structural equation modeling approach to explaining teachers' adoption of digital technology in education. Computers and Education, 128, 13-35. https://doi.org/10.1016/j.compedu.2018.09.009

Shevchenko, M. V. (2018). The role of authentic videos in teaching English at technical universities. Advanced Education, 2015(4), 66-70. https://doi.org/10.20535/2410-8286.57306

Tri, D. H., \& Nguyen, N. H. T. (2014). An exploratory study of ICT use in English language learning among EFL university students. Teaching English with
Technology, 14(4), 32-46.

Wang, Y. C., \& Hsu, L. (2020). Shall we go to the MALL? - Students' perceptions of a business English learning app. International Journal of Information and Education Technology, 10(2), 110-116. https://doi.org/10.18178/ijiet.2020.10.2.1348

Weng, F., Yang, R. J., Ho, H. J., \& Su, H. M. (2018). A tambased study of the attitude towards use intention of multimedia among school teachers. Applied System Innovation, $\quad 1(3)$, $1-9$. https://doi.org/10.3390/asi1030036

Zhang, D., \& Pérez-Paredes, P. (2019). Chinese postgraduate EFL learners' self-directed use of mobile English learning resources. Computer Assisted Language Learning, $\quad 0(0)$, $1-26$. https://doi.org/10.1080/09588221.2019.1662455

Zhang, H., Song, W., \& Burston, J. (2011). Re-examining the effectiveness of vocabulary learning via mobile phones. Turkish Online Journal of Educational Technology, 10(3), 203-214. 